\title{
The role of stand composition on pre-dispersal seed predation in Austrocedrus chilensis (Cupressaceae) in north west Patagonia
}

\author{
El rol de la composición del bosque sobre la depredación predispersiva de semillas en \\ Austrocedrus chilensis (Cupressaceae) en el noroeste de la Patagonia
}

\author{
JOSÉ M. VILLACIDE* \& JUAN C. CORLEY
}

\author{
Laboratorio de Ecología de Insectos, INTA-EEA Bariloche CC 277, CP 8400 San Carlos de Bariloche, \\ Río Negro, Argentina \\ *e-mail for correspondence: jvillacide@bariloche.inta.gov.ar
}

\begin{abstract}
We studied the variability of pre-dispersal seed predation by insects on Austrocedrus chilensis (Cupressaceae). This is a dioecious conifer endemic to southern South America (central Chile and the Chilean Argentinean Patagonia) that grows naturally in pure and mixed stands, typically in association with broadleaved Nothofagus species. Seeds are attacked while still inside the cones, mainly by larvae of Nanodacna austrocedrella (Lepidoptera: Elachistidae). Our working hypothesis was that observed variations in pre-dispersal seed damage levels were related to forest stand composition, specifically to the relative abundance of A. chilensis versus accompanying Nothofagus species. We compared seed predation levels in six pairs of sites using a block design which included a mixed and a pure stand for each paired site. At each site, we manually collected 50 closed seed cones from each of five neighbouring adult trees of A. chilensis. Predispersal seed damage was highly variable among trees and sites, with values ranging between 16.7 to $73.0 \%$ of seeds damaged. We found significant differences in predation rates among stands differing in canopy composition. In mixed stands, with Nothofagus, the proportion of seeds attacked was always greater than that observed in the paired pure A. chilensis stand. We showed that canopy composition influenced the level of pre-dispersal seed predation by insects, supporting the hypothesis that damage increases in mixed stands. Our study is the first to present data on variations of pre-dispersal seed predation in A. chilensis at a large spatial scale, examining the effects of forest type. This information may be useful in planning for commercial $A$. chilensis seed harvesting, as well as for the conservation this endemic conifer.
\end{abstract}

Key words: Cupressaceae, insect herbivory, associational susceptibility, associational damage, Nanodacna austrocedrella.

\section{RESUMEN}

Estudiamos la variabilidad en la depredación predispersiva de semillas por insectos en Austrocedrus chilensis (D. Don) Pic. Serm. \& Bizzarri (Cupressaceae). Esta especie es una conífera dioica endémica del suroeste de Sudamérica (Chile central y Patagonia chilena y argentina), que crece naturalmente en bosques puros y mixtos típicamente asociada con especies latifoliadas del género Nothofagus. Las semillas de este árbol son atacadas en su fase predispersiva, principalmente por las larvas de Nanodacna austrocedrella (Lepidoptera: Elachistidae). Nuestra hipótesis de trabajo fue que las variaciones observadas en los niveles de daños predispersivos están relacionadas con la composición del bosque, específicamente la proporción de A. chilensis relativa a su acompañante Nothofagus dombeyi. Comparamos los niveles de depredación en seis pares de sitios según un diseño en bloque, incluyendo un bosque mixto y uno puro para cada sitio. En estos, seleccionamos cinco árboles adultos de A. chilensis de los cuales colectamos manualmente 50 conos cerrados por árbol. El nivel de daño predispersivo fue altamente variable, con los valores entre el 16,7 y el 73,0 \% de semillas afectadas. Encontramos diferencias significativas en tasas de la depredación según la composición del bosque, siendo siempre mayor el impacto observado en los bosques mixtos que en los bosques puros. Demostramos que la composición del bosque puede determinar el nivel de daño sobre semillas antes de su dispersión, apoyando la hipótesis de mayor daño en bosques mixtos. Nuestro trabajo es el primero en examinar el efecto del tipo del bosque sobre las variaciones espaciales de las tasas de depredación predispersiva de semillas en A. chilensis a escala regional. Esta información puede ser de utilidad en la planificación de cosechas comerciales de semillas de A. chilensis y la conservación esta conífera endémica.

Palabras clave: Cupressaceae, herbivoría por insectos, susceptibilidad asociativa, daño asociativo, Nanodacna austrocedrella. 


\section{INTRODUCTION}

Plant-insect interactions, particularly herbivory and seed predation, have attracted a considerable research interest since the early days of ecology (Southwood 1961). A major issue, with both theoretical and applied implications, concerns our understanding of observed variations in insect attack, both between and within plant species. Spatial variability in herbivory levels is relevant to community structure and persistence, and is central to agriculture and forestry when pests are involved.

Recent studies have analyzed the influence of vegetation structure on insect herbivory levels in a focal plant species (Karban 1997, White \& Whitham 2000, Rodriguez-Saona \& Thaler 2005). It has been proposed that the vegetation surrounding the focal plant can increase its susceptibility to herbivore attack (the "associational susceptibility hypothesis", Thomas 1986, Brown \& Ewel 1987). A contrasting hypothesis, the "associational resistance hypothesis" predicts instead that insect herbivory is lower within a more diverse plant community (Atsatt \& O'Dowd 1976).

Evidence in favour of both hypotheses has been presented for natural plant communities and crops. For instance, Hambäck et al. (2000) and Stiling et al. (2003) showed that a more diverse surrounding vegetation implied lower insect attack rates on species such as Lythrum salicaria (Lythraceae), Myrica gale (Myricaceae), Borrichia frutescens (Asteraceae) and Iva frutescens (Asteraceae) in their natural environments. In contrast, the opposite pattern, where insect damage is enhanced by the presence of other species in the immediate surroundings, has been observed in Nicotiana attenuata (Solanaceae), Atriplex patula (Quenopodiaceae) and Populus spp. (Salicaceae) (Karban 1997, Rand 1999, White \& Whitham 2000). The main conclusion to be drawn from these studies is that the identity and proximity of neighbors in plant communities plays an important role in determining the degree of herbivore impact.

Although herbivory is often associated with defoliation, other plant parts can be also affected significantly by insects. Seeds are a particularly vulnerable stage of a plant's life cycle, which relates directly to fitness (Harper 1990). High levels of seed predation can directly affect plant recruitment rates and also limit dispersal and colonization of new sites (Janzen 1971, Harper 1990). These aspects in turn, play an important role in plant population dynamics and community structure (Harper 1990, Crawley 1997, Howe \& Brown 1999). Seed predation can occur both before and after seed dispersal. Once dispersed, seeds are affected by a variety of species, including insects and mammals, frequently with generalist feeding habits (Crawley 2000). Predispersal seed predation in turn, is frequently caused by insects, such as the larvae of many species of Lepidoptera (Fenner 1985, Turgeon et al. 1994). These species are usually small, sedentary and specialist feeders (Harper 1990, Crawley 2000).

We studied the spatial variability in predispersal seed predation by insects on $A$. chilensis (D. Don) Pic. Serm. \& Bizzarri (Cupressaceae). This species grows naturally, in pure or mixed species stands, typically in association with broadleaved Nothofagus species and occasionally with other temperate rainforest tree species (Seibert 1982, Veblen et al. 1995). Seeds of A. chilensis are variably attacked while still inside the cones, mainly by the larvae of Nanodacna austrocedrella (Lepidoptera: Elachistidae) (Rapoport \& Drausal 1979, Gomez \& Klasmer 1997, Landry \& Adamski 2004).

Our working hypothesis was that variations in pre-dispersal seed predation levels were related to the canopy composition of stands, specifically to the relative proportion of $A$. chilensis versus accompanying Nothofagus species. We evaluated the predictions of both the "associational susceptibility" and "associational defense" hypotheses. We expected to contribute to advance our understanding the role of surrounding vegetation on insect herbivory in forests, as these studies have largely been focused on shrubs and crops (White \& Whitham 2000). The information may prove useful for the management of natural A. chilensis forests as well as for afforestation for commercial purposes.

\section{MATERIAL AND METHODS}

In northern Patagonia (Argentina) Austrocedrus chilensis has a naturally 
fragmented distribution from $36^{\circ} 30^{\prime}$ to $39^{\circ} 30^{\prime}$ $\mathrm{S}$, and then it grows continuously between $39^{\circ} 30^{\prime}$ to $43^{\circ} 20^{\prime} \mathrm{S}$, covering an estimated total area of more than 141.000 ha (Bran et al. 2004). Such broad distribution encompasses a remarkable gradient of declining precipitation from west to east, which defines three types of A. chilensis dominated forests: mixed, compact (pure A. chilensis) and marginal stands (Dezzotti \& Sancholuz 1991, Pastorino 2000).

Mixed forests occur at sites with an annual precipitation ranging between 1,600-2,000 $\mathrm{mm}$. At these sites, A. chilensis is a co-dominant canopy tree associated mainly with evergreen broad-leaved N.dombeyi (Nothofagaceae). At sites receiving 900-1,600 mm year ${ }^{-1}$, compact forests of A. chilensis in pure stands are common, although exceptionally some mixed stands with $N$. dombeyi can occur. As precipitation drops dramatically eastwards to less than $600 \mathrm{~mm}$ and steppe vegetation begins to dominate the landscape, marginal $A$. chilensis populations are found in low densities and isolated patches (Dezzotti \& Sancholuz 1991).

Nearly half of the populations of $A$. chilensis in Argentina are under some kind of conservation status (i.e., national parks and forest reserves, Bran et al. 2004). In turn, the remaining natural forests are heavily exploited, as this conifer species produces highly valued timber, frequently used in construction. At present, there are no commercial plantations of A. chilensis, and so timber is obtained exclusively from natural forests (Pastorino 2000). Our sampling was carried out within a central area in the westeast distribution of $A$. chilensis, where pure and mixed stands with $N$. dombeyi co-occur. We selected six pairs of sites (replicates) according to a blocked design, which included one mixed and one pure stand for each paired site. Replicates were separated between 7-65 $\mathrm{km}$ over a range of differences in rainfall, soil conditions, and slopes (Fig. 1). Blocking allowed removing the variability in tree characteristics associated with the marked variation in rainfall and soils. At each site, we randomly selected five neighboring (separated by $15 \mathrm{~m}$ on average) adult trees of A. chilensis and during April 2003 we manually collected 50 closed seed cones per tree. At this stage, the annual reproductive cycle concludes with seed cone maturation and shedding of seeds (Pastorino 2000). Sample size was limited by our abilities to access ripe seed cones of canopy trees. The cones were dried at $35^{\circ} \mathrm{C}$ during two days and visually examined, counting the proportion of attacked seeds in each cone. We assumed that damaged seeds, resembling injuries reported by Gomez \& Klasmer (1997) for $N$. austrocedrella, were due to this lepidopteran species.

At each site, we recorded the total amount of trees (adults and saplings) of A. chilensis and their co-dominant species, $N$. dombeyi within a $500 \mathrm{~m}^{2}$ circular plot with centre in one of the trees sampled for cones (Matteucci $\&$ Colma 1982). According to the relative proportion of $A$. chilensis within these plots, we classified each stand as: pure, when only A. chilensis occurred; or mixed when $A$. chilensis was accompanied by $N$. dombeyi. The proportion of seeds attacked per site was arcsine transformed to normalize the data and the influence of forest type on this proportion was compared between pairs of sites by a paired Student t-test (Zar 1996). Data are reported as means $\pm S D$.

\section{RESULTS}

We analyzed a total of 3,000 cones collected from 60 trees. Pre-dispersal seed predation was highly variable among sites, with values ranging between 16.7 to $73.0 \%$ of seeds damaged (Table 1). However, we found significant differences in seed damage between pure and mixed stands (paired Student $\mathrm{t}$-test, $\mathrm{t}_{5}$ $=3.280 ; \mathrm{P}=0.022 ;$ mixed stands: $59.8 \pm 17.2$ $\%$; pure stands: $38.8 \pm 18.7 \%$ ). In mixed stands, where A. chilensis grew in close association with $N$. dombeyi, the proportion of seeds attacked was greater than that observed in pure stands (Fig. 2). In turn, a marginally significant negative trend between the proportion of seed damage and relative density of $A$. chilensis was observed in mixed stands $\left(\mathrm{F}_{1,4}=7.25, \mathrm{P}=0.054\right.$, Table 1$)$. Although we were unable to establish the species responsible for seed predation in the present study, in all cases seed injury clearly resembled that caused by N. austrocedrella as described by Gómez \& Klasmer (1997). 


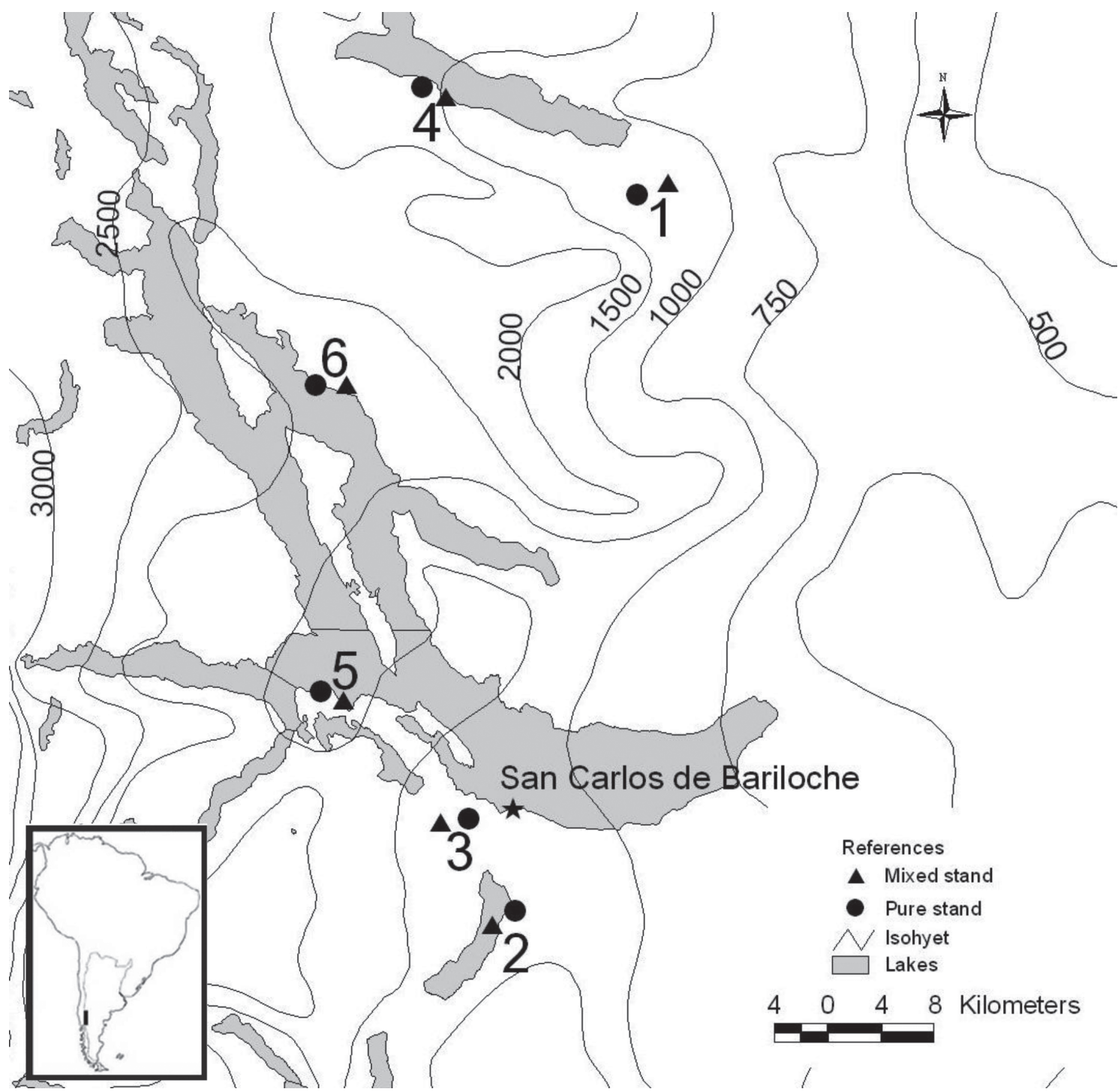

Fig.1: Location of sampling sites within the study area. Mixed stands are shown by triangles and pure stands by full circles. Black lines show annual mean precipitation according to Cordon et al. (1993).

Ubicación de los sitios de muestreo en el área de estudio. Los bosques mixtos son mostrados como triángulos y los puros como círculos llenos. Las líneas negras muestran el nivel de precipitación media anual, según Cordon et al. (1993).

\section{DISCUSSION}

Pre-dispersal seed predation in A. chilensis populations of north west Patagonia, Argentina, was spatially variable reaching high levels at least during the year of this study. Past work has also reported variable levels of pre-dispersal insect seed damage in this conifer in the same region. However, our results differed from previous work. While Rapoport \& Drausal (1979) and Contardi
(1995) described lower seed injury rates (2.926.7 and $13.47 \%$, respectively), Gómez \& Klasmer (1996), and Peñaloza et al. (in Bustamante 1997) reported much larger seed damage levels (56-61 and $98 \%$ respectively). It must be noted, however, that in contrast to the present work, previous studies estimated seed predation levels from damage to single trees or populations, with limited or no spatial replication (Crawley 2000, Hambäck \& Beckerman 2003). 


\section{TABLE 1}

Mean annual precipitation, geographical location, forest composition and proportion of attacked seeds of Austrocedrus chilensis, for each paired site, including one mixed and one pure stand (see text for details). Relative abundance of A. chilensis is the \% of individuals relative to Nothofagus dombeyi. Precipitations values were estimated from Cordon et al. (1993)

Precipitación media anual, ubicación geográfica, composición del bosque y proporción de semillas atacadas de Austrocedrus chilensis, para cada par de sitos, incluyendo un bosque mixto y uno puro (para detalles, ver texto). La abundancia relativa de A. chilensis es el \% de individuos respecto a Nothofagus dombeyi. Los valores de precipitación fueron estimados según Cordon et al. (1993)

\begin{tabular}{|c|c|c|c|c|c|c|c|c|c|}
\hline \multirow[b]{2}{*}{$\begin{array}{l}\text { Site } \\
\text { pair }\end{array}$} & \multirow[b]{2}{*}{$\begin{array}{c}\text { Annual } \\
\text { mean } \\
\text { precipitation } \\
(\mathrm{mm})\end{array}$} & \multicolumn{4}{|c|}{ Mixed stand } & \multicolumn{4}{|c|}{ Pure stand } \\
\hline & & Latitude & Longitude & $\begin{array}{l}\text { Relative } \\
\text { abundance } \\
\text { of } A . \\
\text { chilensis } \\
(\%)\end{array}$ & $\begin{array}{c}\text { Attacked } \\
\text { seeds }(\%) \\
(\%)\end{array}$ & Latitude & Longitude & $\begin{array}{l}\text { Relative } \\
\text { abundance } \\
\text { of } A \text {. } \\
\text { chilensis } \\
(\%)\end{array}$ & $\begin{array}{l}\text { Attacked } \\
\text { seeds }(\%)\end{array}$ \\
\hline 1 & 1,100 & -40.69 & -71.26 & 24 & 67.9 & -40.70 & -71.27 & 100 & 31.2 \\
\hline 2 & 1,300 & -41.19 & -71.39 & 71 & 25.4 & -41.18 & -71.38 & 100 & 16.7 \\
\hline 3 & 1,400 & -41.13 & -71.45 & 18 & 73.0 & -41.12 & -71.42 & 100 & 55.7 \\
\hline 4 & 1,500 & -40.65 & -71.43 & 22 & 64.4 & -40.63 & -71.48 & 100 & 19.4 \\
\hline 5 & 1,600 & -41.05 & -71.53 & 21 & 65.1 & -41.04 & -71.55 & 100 & 59.2 \\
\hline 6 & 1,800 & -40.83 & -71.54 & 60 & 63.1 & -40.82 & -71.57 & 100 & 50.3 \\
\hline
\end{tabular}

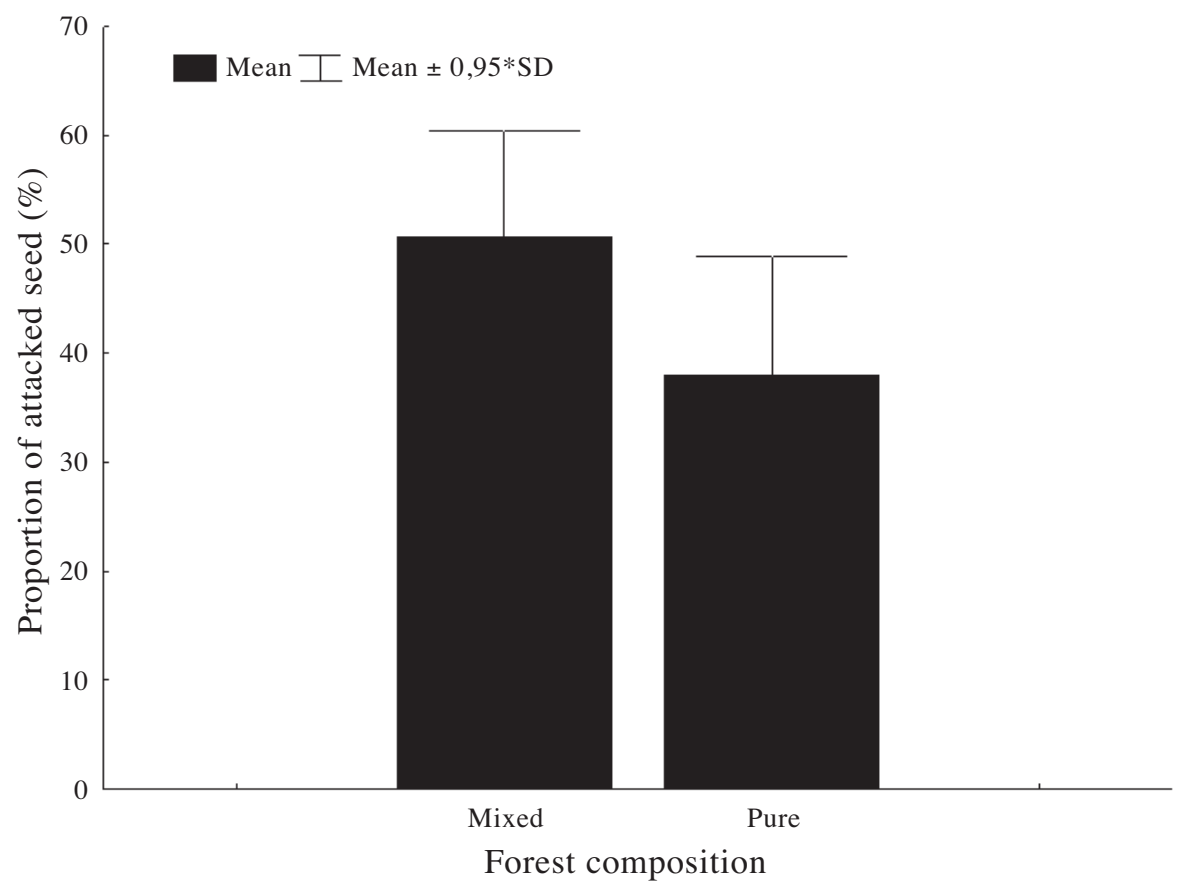

Fig. 2: Predispersal seed injury in A. chilensis according to forest composition. Significantly lower impact was observed when A. chilensis grows in a pure stands (paired Student $\mathrm{t}_{5}=3.280, \mathrm{P}=$ 0.022).

Nivel de daño predispersivo en semillas de A. chilensis según la composición del bosque. Se observó un impacto significativamente menor cuando $A$. chilensis crece en bosques puros $\left(\mathrm{t}_{5}\right.$ pareado $\left.=3,280 ; \mathrm{P}=0,022\right)$. 
Seed damage during the pre-dispersal phase in A. chilensis stands is highly variable both among sites within the west-east precipitation gradient and between mixed and pure stands. The observed variability in insect attack levels could be related to abiotic conditions where trees grow. However, for a given precipitation regime within the west-east gradient, we persistently recorded significantly higher damage levels in mixed stands than in pure stands. These results provide strong evidence for the importance of stand composition on the intensity of plant herbivory, regardless of differences in precipitation, soils or altitude (Atsatt \& O'Dowd 1976, Rand 1999).

The "associational susceptibility" hypothesis (Thomas 1986, Brown \& Ewel 1987), predicts that a focal plant species that occurs in mixed patches with other species, is more likely to be attacked by herbivores than when occurring in monospecific patches. One possible mechanism to explain such pattern (Harper 1990) is the availability of floral resources for an herbivore species whose adults feed on nectar (e.g., Lepidoptera; Brody 1997). In this way, nectar resources for adult Lepidoptera within the patch or stand, provided by trees other than the conifer A. chilensis may influence herbivory levels by their larvae. The risk of herbivory may therefore be modified when a focal-plant occurs in close proximity to nectar sources (Karban 1997). Although we have no definitive clue to the mechanisms that may explain the observed predation pattern differing between mixed and pure stands of $A$. chilensis, the relative frequency of $A$. chilensis trees, with respect to accompanying $N$. dombeyi, may be playing an important role on the probability of encounter by herbivores (Hambäck \& Beckerman 2003). In this sense, we note that even in mixed stands, there is an inverse trend between the proportion of attacked seeds and the relative frequency of A. chilensis (see table 1).

In contrast to past evidence indicating that the associational damage hypothesis applied to herbivores with generalist behaviour (White \& Whitham 2000), in our example, pre-dispersal seed predation is most probably caused primarily by a specialist insect. Little is known, however, about the ecology of $N$. austrocederella, although damage to $A$. chilensis seeds by this species is well known. Gomez \& Klasmer (1997) first reported some basic biology of this Lepidoptera; and recently, Landry \& Adamski (2004) examined the morphology and taxonomic position of this species. As most Lepidoptera, short-lived adults of $N$. austrocedrella feed on nectar sources, whereas larvae are herbivorous. Pupation occurs under the bark of trees in the surroundings. Specificity to A. chilensis is likely, given the marked degree of phenological synchronization with their host (Gómez \& Klasmer 1997).

Our study is the first to report the levels of pre-dispersal seed predation in populations of $A$. chilensis at a large spatial scale. We show that, at least at the spatial scale studied and for the year 2003, canopy composition (mixed versus pure stands) can lead to large differences in predispersal seed predation levels. In this context, and contrary to the general ideas derived from insect pest control work that propose that plant diversity brings about reduced insect attack (e.g., Pimentel 1961), our results suggest that pure stands are less prone to damage by insect seed predators, at least during the pre-dispersal phase. In addition, we show that associational damage may be also observed for specialist herbivores, as most pre-dispersal seed predators are. These findings emphasize the importance of considering the biotic environment (through spatially replicated sampling programs) together with the behavioral traits and foraging resources of adults and larvae of the herbivores involved. We offer new evidence in favour of the associational susceptibility hypothesis in natural forests, providing further elements for understanding plant-herbivore interactions (Hambäck \& Beckerman 2003). From an applied point of view, knowledge of factors that modify herbivory attack in A. chilensis may prove useful in planning commercial seed harvesting and enhancing the conservation this endemic conifer of Patagonia.

\section{ACKNOWLEDGEMENTS}

This study was partially sponsored by the British Ecological Society - Small Ecological Projects Grants (\#2103) and PN-FOR (\#4232) INTA. N. Ferrero, M. Pastorino, P. Sackmann, and an anonymous reviewer provided very helpful comments during several stages of this work. J.C. Corley is a research fellow of CONICET. 


\section{LITERATURE CITED}

ATSATT P \& D O’DOWD (1976) Plant defense guilds. Science 193: 24-29.

BRAN D, A PÉREZ, D BARRIOS, MJ PASTORINO, L GALLO \& J AYESA (2004). Natural range of the "Patagonian cypress" in Argentina - scale 1:250.000. Proceedings: IV Southern Connections Conference. Southern temperate ecosystems \& biota: contributions towards a global synthesis. University of Cape Town, South Africa. $126 \mathrm{pp}$.

BRODY AK (1997) Effects of pollinators, herbivores, and seed predators on flowering phenology. Ecology 78: 1624-1631.

BROWN BJ \& JJ EWEL (1987) Herbivory in complex and simple tropical successional ecosystems. Ecology 68: 108-116.

BUSTAMANTE R (1997) Depredación de semillas en los bosques templados de Chile. In: Armesto J, C Villagrán \& M Arroyo (eds) Ecología de los bosques nativos de Chile: 265-278. Editorial Universitaria, Santiago, Chile.

CONTARDI L (1995) Morfología, estructura y calidad de semillas de -Austrocedrus chilensis- (D. Don) Flor. Et Bout. Publicación técnica 23, Centro de Investigación y Extensión Forestal Andino Patagónico, Esquel, Argentina. 41 pp.

CORDON V, J FORQUERA \& J GASTIAZORO (1993) Estudio microclimático del área cordillerana de sudoeste de la provincia de Río Negro "cartas de precipitación". Universidad Nacional del Comahue, Río Negro, Argentina. 19 pp.

CRAWLEY MJ (1997) Plant ecology. Second edition. Blackwell Science, Oxford, United Kingdom.

CRAWLEY MJ (2000) Seed predators and plant population dynamics. In: Fenner M (ed) Seeds: the ecology of regeneration in plant communities: $167-$ 182. CABI Publishing, Wallingford, United Kingdom.

DEZZOTTI A \& L SANCHOLUZ (1991) Los bosques de Austrocedrus chilensis en Argentina: ubicación, estructura y crecimiento. Bosque (Chile) 12: 43-52.

FENNER M (1985) Seed ecology. Chapman \& Hall, London, United Kingdom. 151 pp.

GOMEZ C \& P KLASMER (1997) Ciclo biológico de un microlepidóptero que ataca los frutos y semillas del ciprés de la cordillera [Austrocedrus chilensis (D. Don) Fl. et Bout]. Bosque (Chile) 18: 31-37.

HAMBÄCK P, J AGREN \& L ERICSON (2000) Associational resistance: insect damage to purple loosestrife reduced in thickets of sweet gale. Ecology 81: 1784-1794

HAMBÄCK P \& AP BECKERMAN (2003) Herbivory and plant resource competition: a review of two interacting interactions. Oikos 101: 26-37.

HARPER J (1990) Population biology of plants. Eighth edition. Academic Press, London, United Kingdom. $892 \mathrm{pp}$

HOWE HF \& JS BROWN (1999) Effects of birds and rodents on synthetic tallgrass communities. Ecology 80: 214-229.

JANZEN DH (1971) Seed predation by animals. Annual Review of Ecology and Systematics 2: 465-492.
KARBAN R (1997) Neighbourhood affects a plant's risk of herbivory and subsequent success. Ecological Entomology 22: 433-439.

LANDRY JF \& D ADAMSKI (2004) A new species of Nanodacna Clarke (Lepidoptera: Elachistidae: Agonoxeninae) feeding on the seeds of Austrocedrus chilensis (Cupressaceae) in Andean Argentina. Journal of the Lepidopterist's Society 58: $100-113$

MATTEUCCI S \& A COLMA (1982) Metodología para el estudio de la vegetación. Organización de los Estados Americanos, Washington, District of Columbia, USA. 168 pp.

PASTORINO M (2000) Genetic variation and reproduction system of Austrocedrus chilensis (D.Don) Florin et Boutelje, a cypress endemic to the AndeanPatagonian forest. PhD thesis, Cuvillier Verlag, Göttingen, Germany. 167 pp.

PIMENTEL D (1961) Species diversity and insect population outbreaks. Annals of Entomological Society of America 54: 76-86.

RAND T (1999) Effects of environmental context on the susceptibility of Atriplex patula to attack by herbivorous beetles. Oecologia 121: 39-46.

RAPOPORT E \& B DRAUSAL (1979) Tácticos y estrategas r, K y "S O S". In: Rabinovich, J \& G Halffteer (eds) Tópicos de ecología contemporánea: 111-128. Fondo de Cultura Económica, México.

RODRIGUES-SAONA C \& J THALER (2005) Herbivoreinduced responses and patch heterogeneity affect abundance of arthropods on plants. Ecological Entomology 30: 156-163.

SEIBERT P (1982) Carta de vegetación de la región de El Bolsón y su aplicación a la planificación del uso de la tierra. Fundación para la Educación, la Ciencia y la Cultura, Buenos Aires, Argentina. 120 pp.

SOUTHWOOD TR (1961). The number of species of insect associated with various trees. Journal of Animal Ecology 30: 1-8.

STILING P, AM ROSSI \& MV CATTELL (2003) Associational resistance mediated by natural enemies. Ecological Entomology 28: 587-592.

THOMAS C (1986) Butterfly larvae reduce host plant survival in vicinity of alternative host species. Oecologia 63: 90-105.

TURGEON J., A ROQUES \& P DE GROOT (1994) Insect fauna of coniferous seed cones: diversity, host plant interactions, and management. Annual Review of Entomology 39: 179-212.

VEBLEN TT, BR BURNS, T KITZBERGER, A LARA \& R VILLALBA (1995) The ecology of the conifers of southern South America. In: Enright NS \& RS Hill (eds.) Ecology of the southern conifers: 120155. Melbourne University Press, Parkville, Australia.

WHITE J \& T WHITHAM (2000) Associational susceptibility of cottonwood to a box elder herbivore. Ecology 81: 1795-1803.

WHITHAM T (1989) Plant hybrid zones as links for pests. Science 44: 1490-1493.

ZAR JH (1996) Biostatistical análisis. Third edition. Prentice Hall International, Englewood Cliffs, New Jersey, USA. 662 pp. 
